International Journal of Engineering \& Technology, $7(2.13)(2018) 240-246$
International Journal of Engineering \& Technology
Website: www.sciencepubco.com/index.php/IJET
Research Paper

\title{
Effective polyurethane compositions filled with industrial wastes
}

\author{
Goncharova Margarita Alexandrovna ${ }^{1}$ *, Korneeva Anastasia Olegovna ${ }^{1}$, Korneev Oleg Olegovich ${ }^{1}$, Hameed \\ Ghalib Hussain Al-Surraiwy ${ }^{1}$ \\ ${ }^{1}$ Lipetsk state technical University, Russia \\ *Corresponding author E-mail:
}

\begin{abstract}
Formulations are developed and optimized for of rigid polyurethane foams filled with converter slag. The optimum content of the filler is $30 \%$. Polyurethane compositions have the following characteristics: average density $-42.59 \mathrm{~kg} / \mathrm{m} 3$, compressive strength at $10 \%$ deformation $-0.293 \mathrm{MPa}$, water absorption by volume $1.71 \%$, coefficient of thermal conductivity $-0.028 \mathrm{~W} / \mathrm{m} \cdot 0 \mathrm{C}$. Polyurethane foams are applied in sandwich panels, multi-layer roof constructions and for the manufacture of fixing systems for metal rolled.

Sandwich panels with polyurethane foam insulation and sheathing of specialized panels are designed for the construction of pre-fabricated residential buildings. The forecasting of polyurethane durability in building structures as thermal insulation in sandwich panels the foam lifespan is about 75 years, which is approximately two times greater than that of the unreinforced foam.

Layered roof structures with modified rigid polyurethane foam are used for buildings and structures for various purposes. Their use makes it possible to solve several tasks: creating a complete architectural image, ensuring high strength and deformation characteristics with good noise and heat insulation, minimization when mounting. The use of lightweight, transportable and technologically advanced roofing elements in conditions of mass production creates significant opportunities for industrial construction. The proposed foam fixing systems during shipping rolled metal in containers makes it possible to exclude the possibility of the longitudinal and transverse shift of pallets with rolls, to protect metal from damage, to simplify the design of the foxing elements, reduce the production cost, and minimize the amount of time for fixing metal rolls in the container.
\end{abstract}

Keywords: Technogenic Materials; Rigid Polyurethane Foam; Converter Slag; Durability; Roof Structures; Per-Fixing System; Polymer Composite Material.

\section{Introduction}

Converter slags are wastes of steelmaking processes. They have a rather complicated chemical and mineral composition, as it consists of oxides, silicates, sulfides. Currently, approximately $60 \%$ of all steel is produced by leading Russian metallurgical enterprises. In the Russian Federation, BOF production is carried out on 22 converters (eight workshops). Recently there has been a steady trend of a substantial increase in melting oxygen Converter steel.

Converter slags are comprised by oxides, silicates, sulphides impurities resulting from the interaction of raw materials (iron and scrap) with oxygen, slag forming, mixing and blast furnace slag, and remnants of the lining of the melting equipment. On one steel mill, the output of steelmaking slag can amount to several million tons per year.
This allowed us to determine the highest priority areas of the application of converter slag (Figure 1). It is known that the experience of using slag of ferrous and nonferrous metallurgy in the world and in Russia quite rich. Long research and modern methods have confirmed the possibility of obtaining various building materials with different properties from the waste. The solution to the problem of efficient use of Converter slag will provide for the solution of two urgent tasks: provision of raw materials for the production of new and traditional materials and products and the elimination of negative impacts of waste on the environment in case of lack of demand and the need for storage and warehousing.

This will improve their construction and technical properties, in particular, the will increase the coefficient of structural quality, reduce flam-mobility and minimize the cost of finished products (Figure 2). 


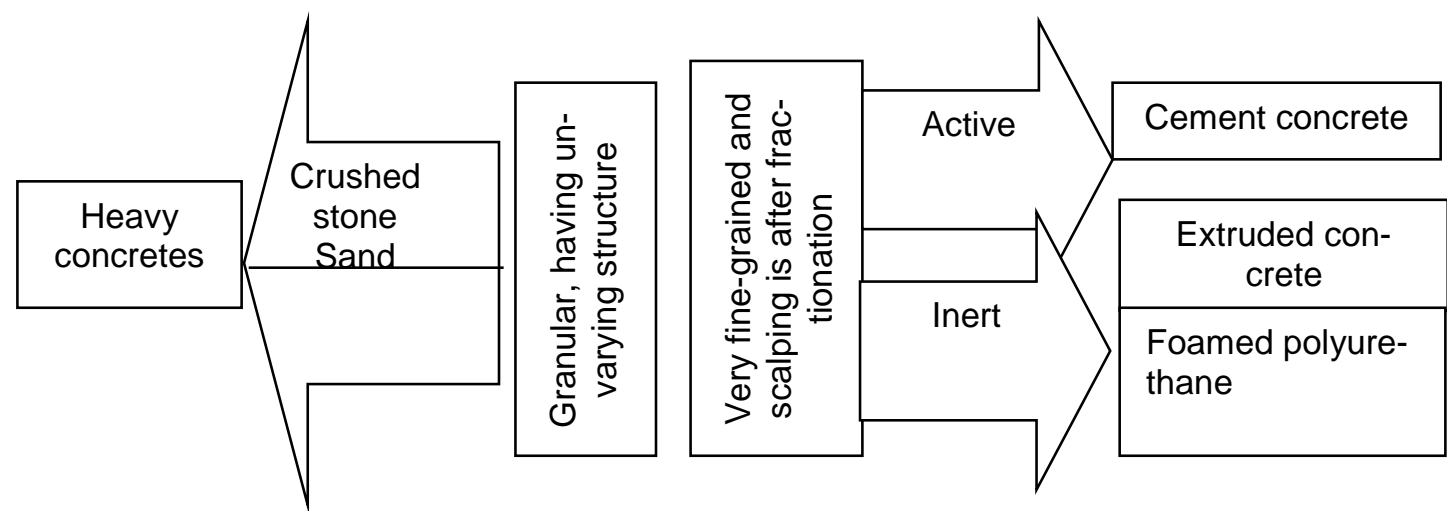

Fig. 1: Perspective Fields of the Application of Converter Slag, Accepted as Objects of Research.

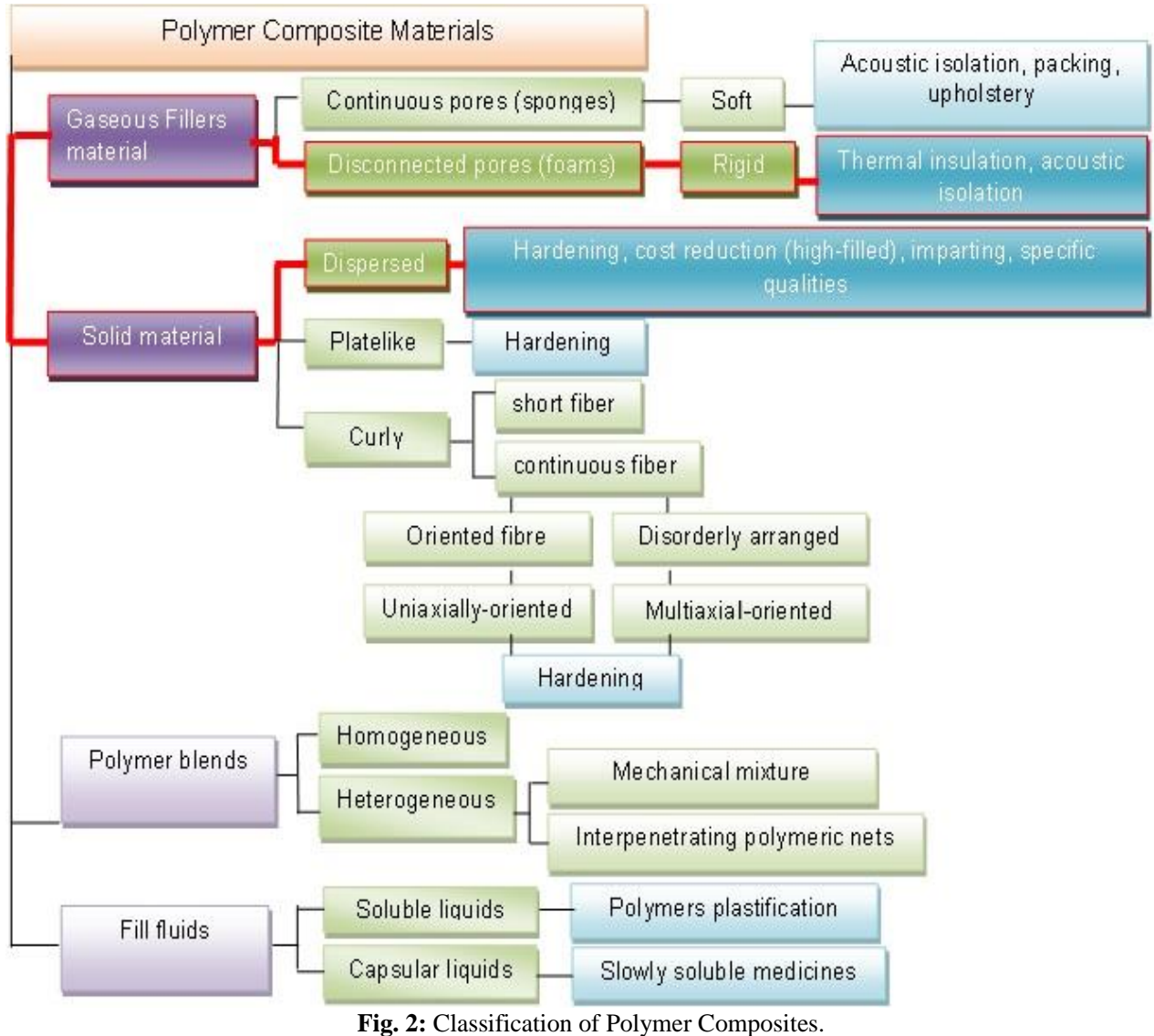

One of the promising directions of the use of converter slag is the production of thermal insulation foams, in particular, polyurethane foams.

\section{Methods}

A two-stamp system TIMPOL-210 was used as a raw material, which is intended for the manufacture of sandwich panels by a discontinuous process, for the production of isothermal vans of vehicles, refrigerators, for the construction of buildings, pavilions, industrial low temperature freezers and other products for thermal isolation. Polyurethane foam the derived from components of the system, has a good cure, low thermal conductivity, as well as a uniform distribution of density by the volume of the product. The 210 TIMPOL System consists of the polyol component (component "A") "Timpol A-210" and polyisocyanate (component "B") -polymer difenilmetandiizocianat. The recommended ratio of components "A" to component "B" is 100:160. The characteristics of the materials used are shown in Table 1.

As a filler we made use of converter slag, which has a porous structure and represents a deviation waste production of BOF-dark grey color. The chemical composition of the converter slag is represented by the following oxides, $\%$ : $\mathrm{FeO}-8,0 \ldots 21,1 ; \mathrm{SiO}_{2}-$ $12,7 \ldots 17,0 ; \mathrm{CaO}-40.0 \ldots 54.2 ; \mathrm{MgO}-1.9 \ldots 12.6 ; \mathrm{Al}_{2} \mathrm{O}_{3}-1.7 \ldots 8.3$; $\mathrm{MnO}-0.5 \ldots 2.6 ; \mathrm{SO}_{2}-0.03 \ldots 0.19 ; \mathrm{R}_{2} \mathrm{O}_{5}-0.06 \ldots 0.94$ [4]. The particle size of the filler does not exceed $0.3 \mathrm{~mm}$ and in the foam, forming process is embedded in its structure [5].

Table 1: Characteristics of the Components "A" And "B"

\begin{tabular}{lll}
\hline Hydroxyl number, $\mathrm{mg} \mathrm{KOH} / \mathrm{g}$ & $250 \ldots 330$ & - \\
\hline NCO content groups, $\%$ & - & 31 \\
Density, $\mathrm{g} / \mathrm{cm} 3\left(25^{\circ} \mathrm{c}\right)$ & 1.15 & 1.23 \\
Viscosity $\mathrm{MPa} \cdot \mathrm{s}\left(25^{\circ} \mathrm{c}\right)$ & 350 & 200 \\
Storage stability ${ }^{*}, \mathrm{Mon}$. & 3 & 6 \\
Storage temperature, ${ }^{\circ} \mathrm{C}$ & $15 \ldots 25$ & $15 \ldots 25$ \\
\hline
\end{tabular}

When stored in a sealed container in a dry place at provider recommended temperature

The research carried out a series of experiments to determine physico-mechanical properties of tile material that contains converter slag as a filler. Tile the filler is carried was introduce to improve its operational characteristics [6]. The study on properties of foam filled polyurethanes was carried out with the ratio of $\mathrm{A}: \mathrm{B}=100$ : 
160. Polyurethane foam samples were produced with different content of fillers.

Converter slag is evenly distributed in the polymer matrix. Due to the adsorption by fillers of the polymer the polyurethane is clamped to the Plateau-Gibbs, canals which leads to an increase in their weight and, consequently, increases the density and strength of the composition. This is proved by the results of microscopic examination (Figure 3).

(A)

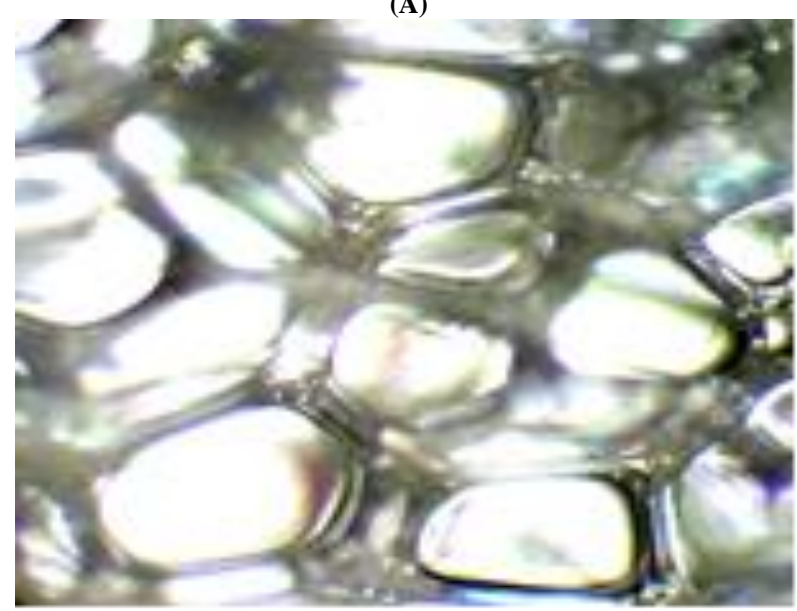

(B)

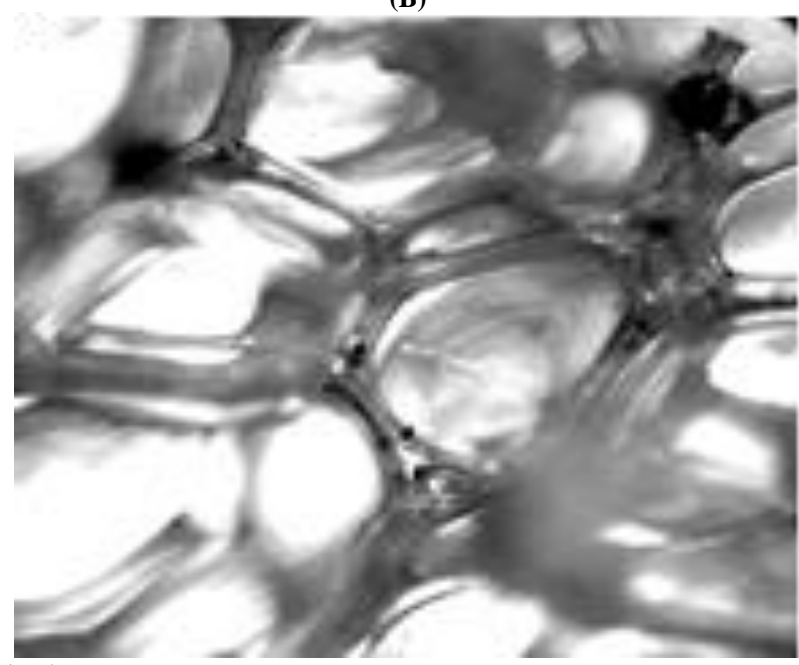

Fig. 3: Polyurethane (Increase $-\times 200)$ Without Filler (A) With The 20\% Content of Converter Slag (B).

The filler was introduced in the polyol component, and after thorough mixing it was mixed with polyisocianate: The study filling interval ranges from 5 to $100 \%$ of the mass of weight, because it provides the correct search for an optimal composition. Further increase of filler along with increased strength characteristics leads to significant increases in average density and thermal conductivity. Constructive quality coefficient (C.Q.C.) is determined by the formula:

$$
\text { C.Q.C. }=\left(\mathrm{R}_{10 \% / \rho_{\mathrm{m}}}\right) 100
$$

Where $\mathrm{R}_{10 \%}$ - compressive strength at $10 \%$ deformation, $\mathrm{MPa}$; $\rho_{\mathrm{m}}$ - average density, $\mathrm{kg} / \mathrm{m}^{3}$;

100 - Sample convenience multiplier.

As a result of the testing of filled with polyurethane foam, the following data were obtained (table 2).
Table 2: Physical-Mechanical Properties of the Filled Polyurethane Foam

\begin{tabular}{|c|c|c|c|c|c|}
\hline $\begin{array}{l}\text { Filler } \\
\text { content, } \% \\
\text { of the mass } \\
\text { of } \\
\text { polyisocya } \\
\text { nate }\end{array}$ & $\begin{array}{l}\text { Avera } \\
\text { ge } \\
\text { densit } \\
\mathrm{y}, \\
\mathrm{kg} / \mathrm{m} 3\end{array}$ & $\begin{array}{l}\text { Strength } \\
\text { at } 10 \% \\
\text { deformati } \\
\text { on, MPa }\end{array}$ & $\begin{array}{l}\text { Construct } \\
\text { ive } \\
\text { quality } \\
\text { coefficien } \\
\mathrm{t}\end{array}$ & $\begin{array}{l}\text { Water } \\
\text { absorption } \\
, \%\end{array}$ & $\begin{array}{l}\text { Heat } \\
\text { co- } \\
\text { effi- } \\
\text { cient } \\
, \\
\mathrm{w} / \mathrm{m} \\
{ }^{\circ} \mathrm{c}\end{array}$ \\
\hline 0 & 33.93 & 0.100 & 0.295 & 3.70 & $\begin{array}{l}0.01 \\
8\end{array}$ \\
\hline 5 & 34.41 & 0.136 & 0.395 & 3.61 & $\begin{array}{l}0.01 \\
9\end{array}$ \\
\hline 10 & 35.52 & 0.181 & 0.510 & 2.53 & $\begin{array}{l}0.02 \\
1\end{array}$ \\
\hline 15 & 36.70 & 0.210 & 0.572 & 2.45 & $\begin{array}{l}0.02 \\
2\end{array}$ \\
\hline 20 & 38.09 & 0.227 & 0.596 & 2.17 & $\begin{array}{l}0.02 \\
4\end{array}$ \\
\hline 25 & 40.62 & 0.261 & 0.643 & 1.79 & $\begin{array}{l}0.02 \\
6\end{array}$ \\
\hline 30 & 42.59 & 0.293 & 0.688 & 1.71 & $\begin{array}{l}0.02 \\
8\end{array}$ \\
\hline 35 & 43.84 & 0.300 & 0.684 & 1.65 & $\begin{array}{l}0.02 \\
8\end{array}$ \\
\hline 40 & 44.35 & 0.304 & 0.685 & 1.60 & $\begin{array}{l}0.02 \\
8\end{array}$ \\
\hline 45 & 45.99 & 0.312 & 0.678 & 1.63 & $\begin{array}{l}0.02 \\
9\end{array}$ \\
\hline 50 & 47.48 & 0.319 & 0.672 & 1.65 & $\begin{array}{l}0.02 \\
9\end{array}$ \\
\hline 55 & 50.02 & 0.327 & 0.654 & 1.70 & $\begin{array}{l}0.03 \\
0\end{array}$ \\
\hline 60 & 52.08 & 0.335 & 0.643 & 1.76 & $\begin{array}{l}0.03 \\
0\end{array}$ \\
\hline 65 & 54.22 & 0.341 & 0.629 & 1.80 & $\begin{array}{l}0.03 \\
1\end{array}$ \\
\hline 70 & 56.84 & 0.347 & 0.610 & 1.88 & $\begin{array}{l}0.03 \\
1\end{array}$ \\
\hline 75 & 59.67 & 0.352 & 0.590 & 1.92 & $\begin{array}{l}0.03 \\
2\end{array}$ \\
\hline 80 & 61.37 & 0.359 & 0.585 & 1.99 & $\begin{array}{l}0.03 \\
2\end{array}$ \\
\hline 85 & 64.92 & 0.364 & 0.561 & 2.07 & $\begin{array}{l}0.03 \\
3\end{array}$ \\
\hline 90 & 67.54 & 0.373 & 0.552 & 2.21 & $\begin{array}{l}0.03 \\
3\end{array}$ \\
\hline 95 & 69.91 & 0.378 & 0.541 & 2.30 & $\begin{array}{l}0.03 \\
4\end{array}$ \\
\hline 100 & 73.84 & 0.385 & 0.521 & 2.38 & $\begin{array}{l}0.03 \\
4\end{array}$ \\
\hline
\end{tabular}

Based on data of table [2] it can be concluded that the optimal content of disperse toxins is their presence in the amount of $30 \%$ (table 3 ), it confirms the most constructive quality coefficient. With this filling in foams, have the following characteristics.

Table 3: Rigid Polyurethane Foams with 30\% Content of Fillers

\begin{tabular}{lllll}
\hline Filler & $\begin{array}{l}\text { Average } \\
\text { density, } \\
\mathrm{kg} / \mathrm{m}^{3}\end{array}$ & $\begin{array}{l}\text { Strength at } \\
10 \% \text { defor- } \\
\text { mation, MPa }\end{array}$ & $\begin{array}{l}\text { Water } \\
\text { absorp- } \\
\text { tion, } \%\end{array}$ & $\begin{array}{l}\text { Thermal con- } \\
\text { ductivity co- } \\
\text { efficient, } \\
\mathrm{w} / \mathrm{m}^{\circ}{ }^{\circ} \mathrm{c}\end{array}$ \\
\hline $\begin{array}{l}\text { Without } \\
\text { filler }\end{array}$ & 33.93 & 0.100 & 3.70 & 0.018 \\
$\begin{array}{l}\text { Converter } \\
\text { slag }\end{array}$ & 42.59 & 0.293 & 1.71 & 0.028 \\
\hline
\end{tabular}

\section{Sandwich panels}

Currently, are becoming increasingly sought-after cottage-type prefabricated low-rise buildings are (Figure 4). This has significantly expanded the range of constructive solutions, introduced new technologies of their manufacturing and construction. The most effective constructive element in this direction is private construction of prefabricated houses. When this panel is used not only as wall panels, but also as floor slabs and roof panels (Figure 5). In Dolgorukovo of the Lipetsk Region "Pearl" LLC manufactures energyefficient sandwich panels intended for low-rise construction. Such 
panels are composed of two sheets of laminated wood chipboard OSB 3, the space between them is filled with foam polyurethane (Figure 6) [7], [8]. In the case of prefabricated residential buildings the sandwich panel polyurethane wears out much faster than the oriented strand board. This leads to greater economic costs, because replacement is simply impossible without dismantling the building. The solution to the problem heater of increasing of durability of precast concrete sandwich panels of polyurethane foam found by introducing functional fillers in formulations of traditional polyurethane foams.

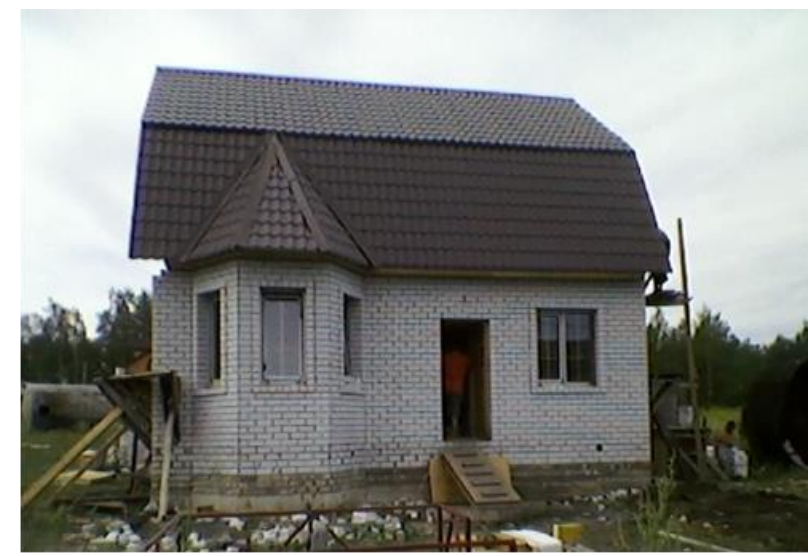

Fig. 4: One-Apartment House.

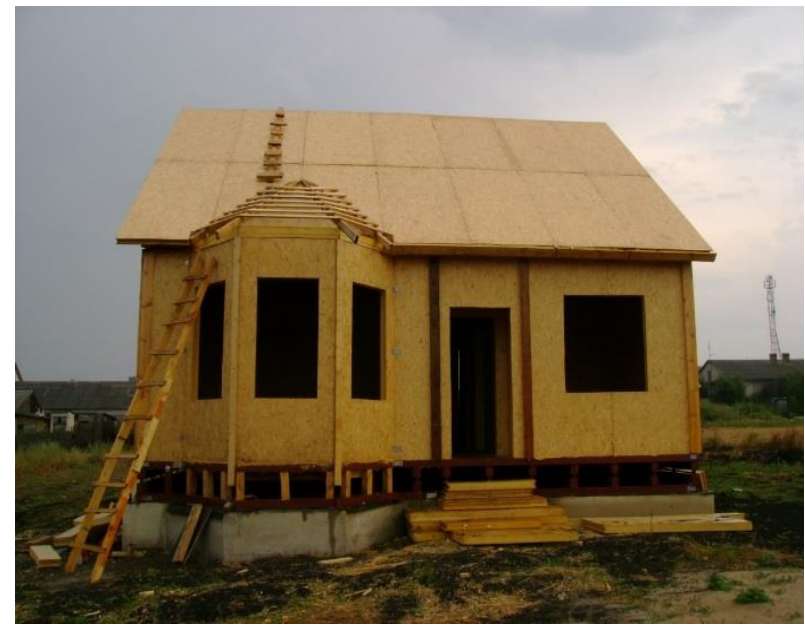

Fig. 5: Individual One-Storey House.
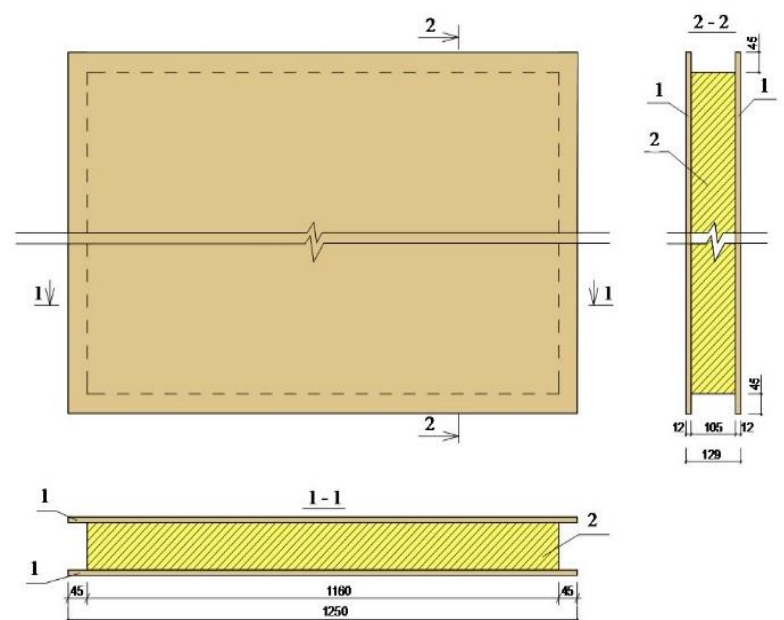

Fig. 6: General View of Sandwich Panel.

1) OSB 3 size $1250 \times 2800 \mathrm{~mm}$

2) filled with polyurethane foam

The prediction of longevity of filled with polyurethane foam in roofing sandwich panels was carried out in the following sequence.
Sustained loading is calculated by the formula:

$\sigma_{\mathrm{I}}=\mathrm{M} / \mathrm{W}=6.95 \cdot 10^{3} / 1.42 \cdot 10^{-3}=4.91 \mathrm{MPa}$,

Where $\mathrm{M}=\mathrm{q} \cdot \mathrm{l}^{2} / 2=1.39 \cdot 10^{3} \cdot 1^{2} / 2=6.95 \cdot 10^{3} \mathrm{H} \cdot \mathrm{m}-$ the bending moment acting on the polyurethane foam

$\mathrm{W}=\delta \cdot \mathrm{c}^{2} /(\mathrm{c}+\delta)=0.012 \cdot 0.129^{2} /(0.012+0.129)=0.0014156$ $\mathrm{m}^{3}$ - resistance moment,

$\mathrm{c}$ - Panel thickness,

$\delta-$ Facing thickness.

In three-layer panels with continuous insulation foam, depending on the stiffness of the facings the core takes on [2-5] percentage of total load [9].

When defining durability, the temperature $\mathrm{T}=40^{\circ} \mathrm{C}$ is taken as the maximum operating temperature. For the calculation, we use the inverse sheaf equation and the values of empirical coefficients from table 4 [10].

For unfilled polyurethane foam:

$\lg \tau=\lg \tau_{m}+\left[\frac{U_{0}-\gamma \sigma}{R T}\left(\frac{T_{m}}{T}-1\right)\right]=12+\frac{-160+765 \cdot 4,33 \cdot 0,05}{4,2 \cdot 4,6 \cdot 0,303}\left(\frac{0,230}{0,303}-1\right)=11,18$

$13+[(-160+1100 \cdot 4,91 \cdot 0,05) / 8,31 \cdot 0,313] \cdot(270 / 313-$

1) (3)

$=9,09$

For polyurethane foam filled with converter slag:

$$
\begin{aligned}
& \lg \tau=\lg \tau_{m}+\left[\frac{U_{0}-\gamma \sigma}{R T}\left(\frac{T_{m}}{T}-1\right)\right]=12+\frac{-160+765 \cdot 4,33 \cdot 0,05}{4,2 \cdot 4,6 \cdot 0,303}\left(\frac{0,230}{0,303}-1\right)=11,18 \\
& 14+[(-149+1064 \cdot 4,91 \cdot 0,05) / 8,31 \cdot 0,313] \cdot(272 / 313- \\
& \text { 1) }(4) \\
& =9.38
\end{aligned}
$$

Table 4: The Empirical Coefficients and the Projected Durability of Polyurethane Foams

\begin{tabular}{lllllll}
\hline $\begin{array}{l}\text { Type of the } \\
\text { polyurethane } \\
\text { foam }\end{array}$ & $\begin{array}{l}\tau_{\mathrm{m}}, \\
\mathrm{sec}\end{array}$ & $\begin{array}{l}\mathrm{T}_{\mathrm{m}}, \\
\mathrm{K}\end{array}$ & $\begin{array}{l}\mathrm{U}_{0}, \\
\mathrm{~kJ} / \mathrm{mol}\end{array}$ & $\begin{array}{l}\gamma, \\
\mathrm{kJ} /(\mathrm{mol}- \\
\mathrm{MPa})\end{array}$ & $\tau, \mathrm{sec}$ & years \\
\hline $\begin{array}{l}\text { Polyurethane } \\
\text { foam without } \\
\text { a filler }\end{array}$ & 1013 & 270 & -196 & -1100 & 109.09 & 39.01 \\
$\begin{array}{l}\text { Polyurethane } \\
\text { foam-filled } \\
\text { with con- } \\
\text { verter slag }\end{array}$ & 1014 & 272 & -170 & -1064 & 109.38 & 76.07 \\
\hline
\end{tabular}

\section{Multilayer roof structure}

In recent years, multilayer structures and elements are increasingly used in construction. Their functional and economic efficiency is caused by a synergistic combination of structures as well as structural and thermal insulation properties of the used materials, working as one.

Multi-layer roof structures are used for buildings and structures of various purpose. Their use solves several problems - the creation of a complete architectural image, ensuring high strength and deformation characteristics with good sound and heat insulation, enables to minimizing costs during installation.

Obtaining a multilayer roof structure, which is a metal tile (Figure 7) covered with modified rigid polyurethane foam, for in a single technological cycle riper is a complex and challenging range of activities and events on the production of high-quality roofing pie, including hydro, steam and thermal insulation. The use of lightweight, portable, and technologically advanced roofing elements in terms of mass production creates opportunities for industrial construction [11], [12]. 


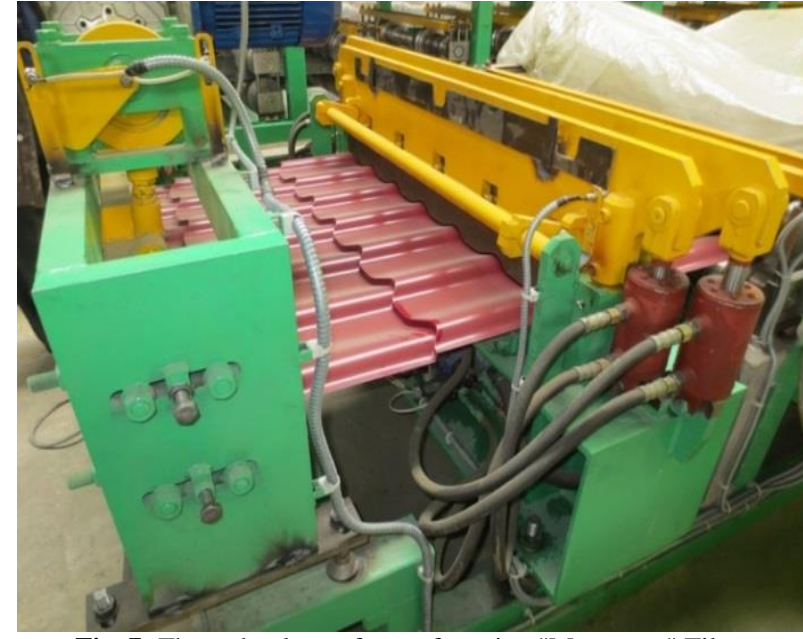

Fig. 7: The technology of manufacturing "Monterrey" Tiles.

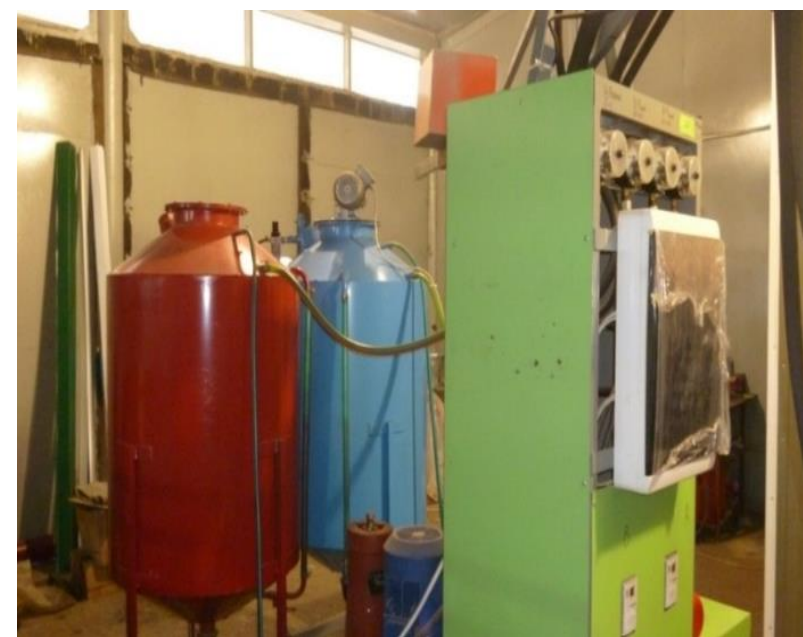

Fig. 8: The equipment for Manufacturing Filled Polyurethane Foam.

When spraying foam as a mixing component, compressed air from the compressor is ussed. The spray gun receives raw materials, and through the upper channel (Figure 8). In the mixing chamber the components are mixed and a mixture exhausts from the output nozzle as a spray torch; the mixture is directed to a metal surface by the operator. Polyurethane components have a high adhesion to a wide variety of materials, the geometry of the surface is of no importance.

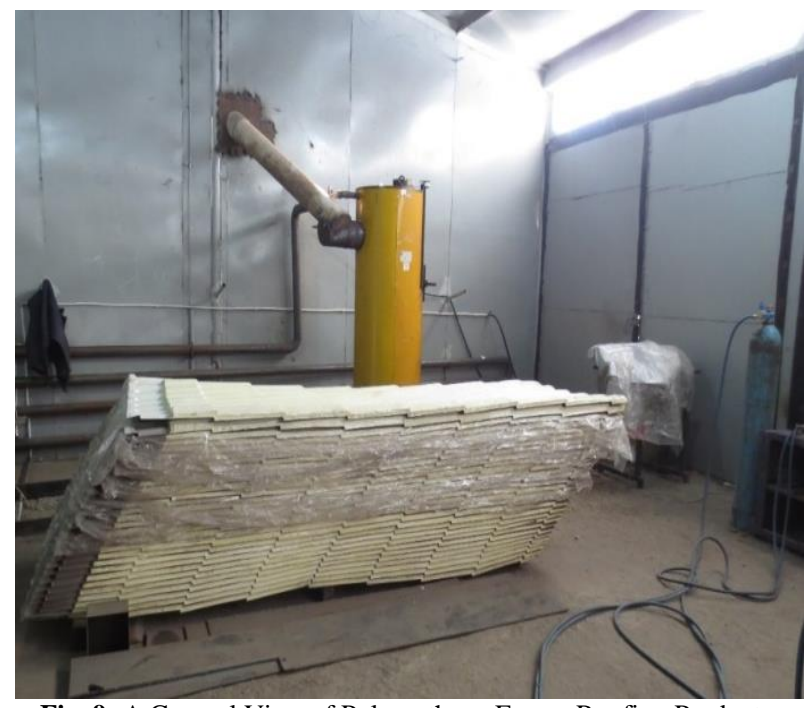

Fig. 9: A General View of Polyurethane Foams Roofing Products.

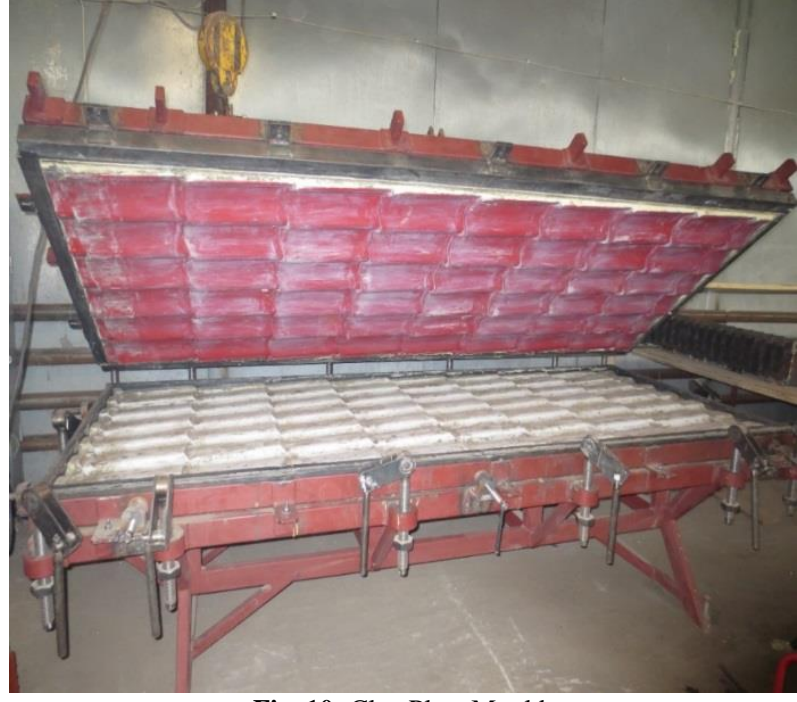

Fig. 10: Clay Plate Mould

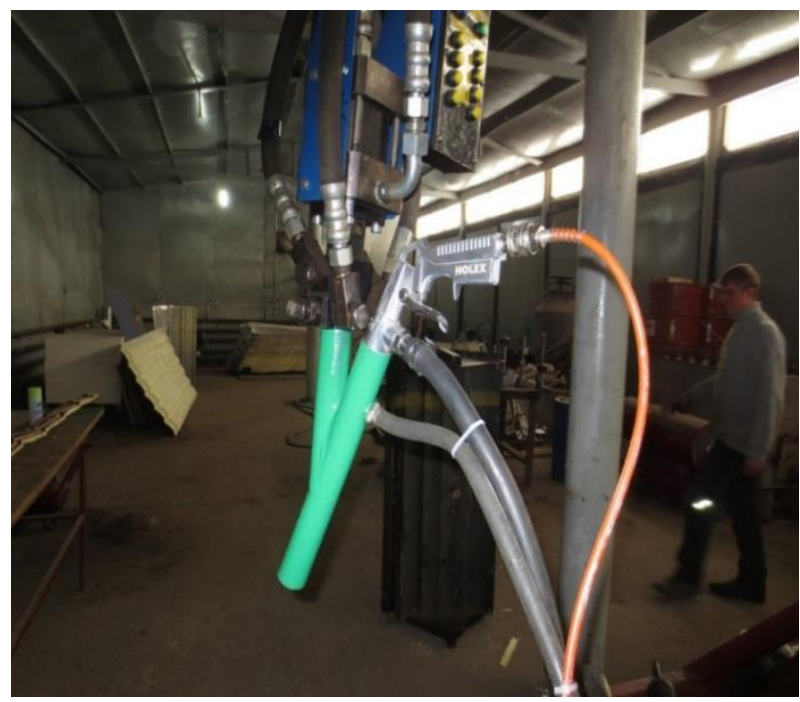

Fig. 11: Equipment for the Manufacture of Rigid Polyurethane Foam.

The technology of multilayer roofing tile (Figures 9, 10, 11) has been implemented by two companies of the Lipetsk region with a total economic effects of 1.5 million rubles.

\section{Polyurethane foam rolled metal fixing sys- tems}

In order to fix roll materials during container transportation by rail and sea transport polyurethane foam notched damped fixing elements are used. Some of them are installed along the height of the coil, the inner surface follows the contour of the coil and the outer surface copies the shape of the walls of the container. Others are made in the form of beams, which are set between the notched fastening elements along their entire height. To provide additional strength, polyurethane foam elements on the outer planes can be reinforced with fiberglass or other similar materials. For additional fixation unilateral durable reinforced adhesive tape may be used which is pasted on the container walls in the vicinity of the proposed location of the coils copying the projections and depressions of the container walls with the subsequent overlap of the tape in the front and back of the whole coil unit. Besides, wooden or other beams of various cross-sections may be applied mounted at the level of pallets, for fixing each transverse row of [2] rolls.

The proposed method of fixing rolled metal in container transportation eliminates the possibility of longitudinal and transverse shifting of the pallets with rolls, protect the metal from damage, to simplifies the design of the fixing elements, reduces their production 
cost, minimizes the time for fixing the rolls of metal in the container.

The technical result is achieved by the fact that the shape of the notched fixing elements in the suggested method of fixing rolled metal makes it possible to further distribute loads on the longitudinal walls of the container and eliminates the possibility of load displacement in braking in the axial direction, and prevents the detachment of reinforced adhesive tape from the walls of the container and, as a result, additionally prevents longitudinal shift of the unit of rolled metal (Figures [12-13] and 14).

Unilateral durable reinforced adhesive tape (1) is pasted on the container wall in the vicinity of the proposed location of the rolls copying the projections and depressions of the walls of the container. Polyurethane foam notched damped fixing elements (3) are attached to the metal roll (2) mounted on a wooden pallet on four sides by means of wrapping polyester tape. The elements are mounted along the height of the roll, there inner surface follows the contour of the roll and the outer surface copies the shape of the walls of the container. The metal is loaded in the container close to the side walls of the container (4) so that the contours of the walls of the container and the fixing elements is aligned. Wooden or other beams (5) are set at the level of pallets, for fixing each transverse row of 2 rolls. Polyurethane foam fixing elements are made in the form of beams set between the notched fixing elements along their entire height. The resulting unit of rolls in the front and back is fixed previously pasted on the walls of the container-reinforced adhesive tape (1).

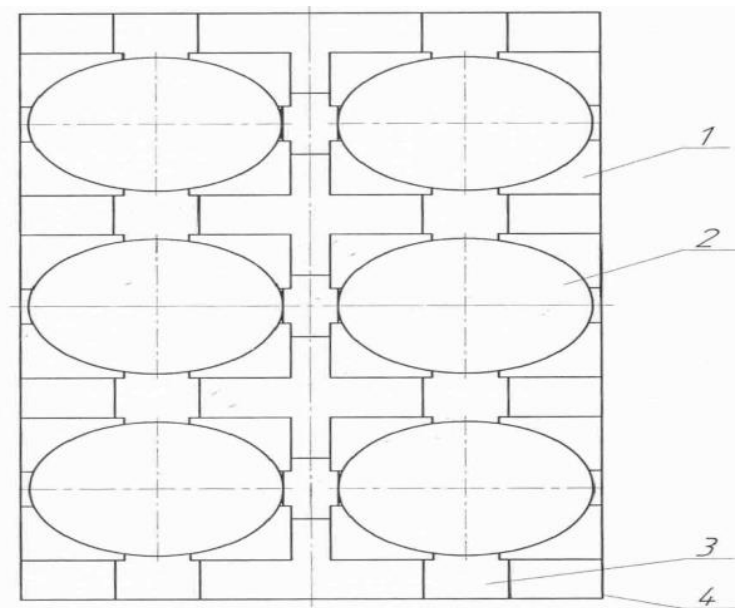

Fig. 12: A Way of Fixing the Roll.

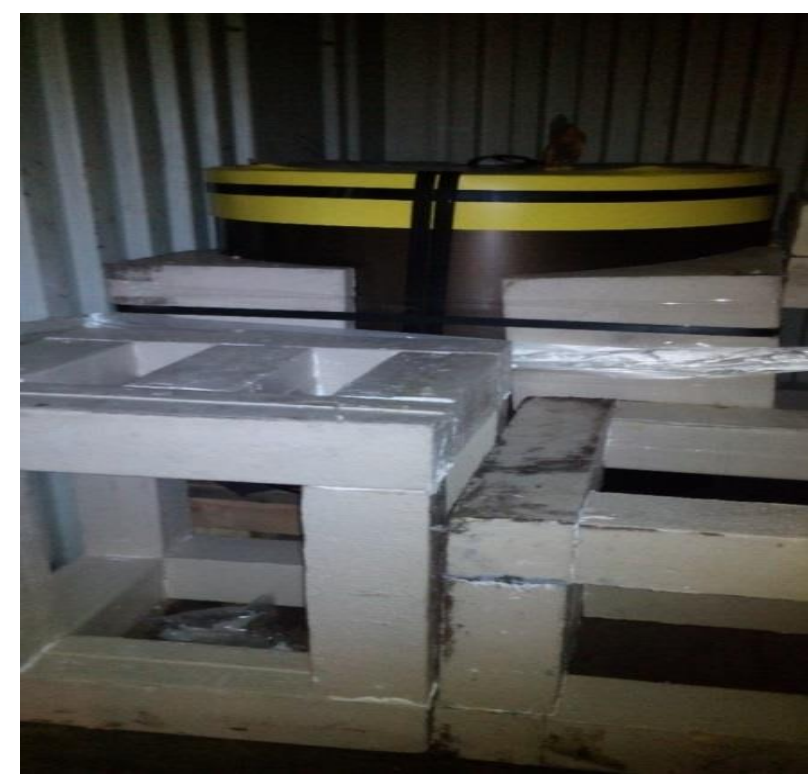

Fig. 13: A General View of the System Figure 14. A Scheme of Fixing the Roll.

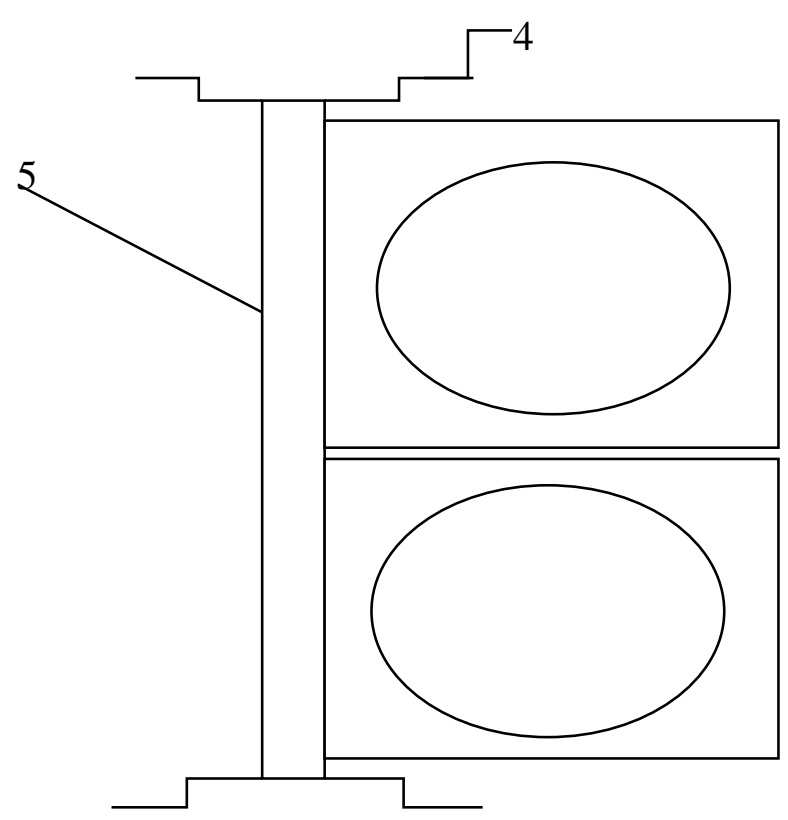

Fig. 14: A Scheme of Fixing the Roll.

\section{Conclusion}

During the filling of polyurethane foam of Converter slag, its strength increased by nearly three times, and projected lifetime of unfilled polyurethane foam in the design pane of the coating is about 75 years (the durability of unfilled polyurethane foam is approximately 40 years). Thus, the use of metallurgical industry waste (converter slag) as a filler of the polyurethane foam is quite appropriate.

\section{References}

[1] Denisov A. V. Rigid polyurethane foams for insulation / A. V. Denisov // Building materials. 2005; 6, P. 21.

[2] Sherstov A.M. Technological features of producing polyurethane foam composites based on polyisocianate / A. M. Sherstov, A. D. Korneev, A. O. Proskuryakova // Composite building materials. Theory and practice: SB. Tr. Intern. Scientific.-tech. Conf. Penza, 2006, P. 311-313.

[3] Korneev A. D. Structure, properties and technology of polymer-composite materials: dis. ... for the degree of Doctor of. Sciences: 05.23.05 / Korneev Alexander. Lipetsk, 1995, 411 p.

[4] Goncharova M. A. Systems of hardening and building composites on the basis of Converter slags / M. A. Goncharova. Voronezh: VGASU, 2012,135 p.

[5] Korneev A. D. Filled polyurethane foam with improved performance characteristics / A. D. Korneev, A. O. Proskuryakova, // Bulletin of the Central regional office. Academic materials of the scientific conference "Problems of architecture, town-planning in the socio-economic development of regions". Tambov - Voronezh. 2012. Issue 11 (for the 20th anniversary of RAACS), P. $227-230$.

[6] Korneev A. D. Rigid polyurethane foam with ultrafine fillers / A. D. Korneev, M. A. Goncharova, A. O. Proskuryakova // Resource - and energy-efficient technologies in the construction complex of the region: collection of scientific works on materials of the international. Scientific. pract. Conf. Saratov: SGTU, 2014, P. 54 - 57.

[7] Proskuryakova A. O. Sandwich panels with insulation of polyurethane foam for the construction of low-rise buildings / A. O Proskuryakova, A. D. Korneev // Collection of abstracts of scientific conference of students and graduate students of Lipetsk state technical University. Lipetsk. 2010, P. 229.

[8] Proskuryakova A. O. Sandwich panels for low-rise housing / A. O. Proskuryakova // School of young scientists in engineering sciences: materials of the regional profile of the seminar. Lipetsk: publishing house of the LGTU. 2009, P. $49-51$.

[9] Ovcharenko E. G. Thermal insulation and energy saving / E. G. Ovcharenko, V. M. Artemyev, B. M. Shoykhet, B. S. Zholudov. 1999 two. - P. $37-42$. 
[10] Goncharova M. A. the Prediction of longevity of filled polyurethane foam in roof sandwich panels / M. A. Goncharova, B. A. Bondarev, A.O. Proskuryakova, // Scientific Bullet of VSUACE. "Construction and architecture" Issue no three (35). Voronezh: VGASU. 2014, P. $31-38$.

[11] Demyanov V. S. Main directions of the tile market in the construction complex of the Penza region [Text] / V. S. Demyanova, A. D. Gusev, G. N. Simakina on // Regional architecture and construction. 2012; 1, P. 193-196.

[12] Goncharova M. A. The technology of composite tiles with insulation-filled polyurethane foam / M. A. Goncharova, A.D. Korneev, G. A. Shatalov / Building materials. - 2014; 3, P. $92-96$. 